\begin{tabular}{|l|l|l|}
\hline \multicolumn{2}{|c|}{ PublisherInfo } \\
\hline \hline PublisherName & $:$ & Palgrave Macmillan UK \\
\hline \hline PublisherLocation & $:$ & London \\
\hline \hline PublisherImprintName & $:$ & Palgrave Macmillan \\
\hline
\end{tabular}

\title{
International comparisons of labour disputes in 2005
}

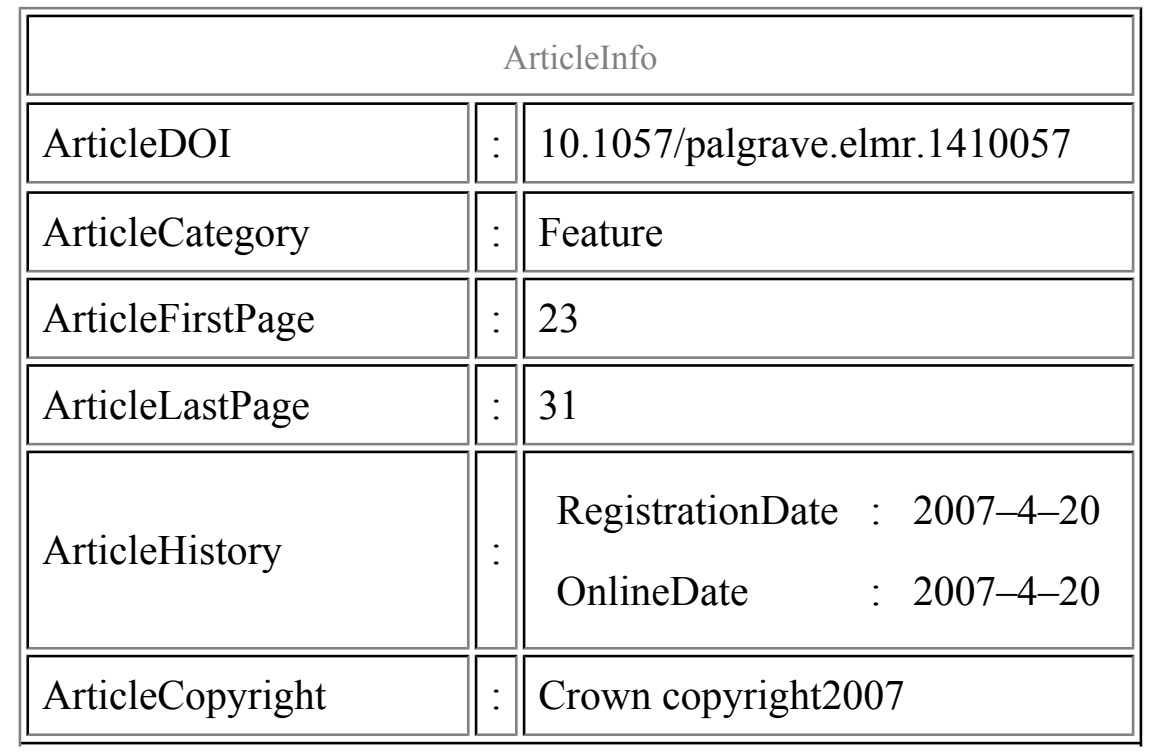


Dominic Hale, ${ }^{\text {Affl }}$

Aff1 Office for National Statistics

\section{Presents data for EU countries and the OECD, comparing overall strike rates between countries and by industry}

This article continues a regular series on international labour disputes and presents data on labour disputes in member countries of the European Union and the Organisation for Economic Co-operation and Development, between 1996 and 2005. Comparisons are made of overall strike rates between countries as well asstrike rates by industry. The article also describes the differences in definitions and coverage of the statistics between countries and how they affect comparability.

\section{Misc}

The Full Text of this article can be found on the National Statistics website (http://www.statistics.gov.uk/elmr/04_07/downloads/ELMR_Apri107_Hale.pdf). 